\title{
Assessment of potability of spring water and its health implication in a hilly village of Uttarakhand, India
}

\author{
Jaspal Singh Chauhan ${ }^{1} \cdot$ Tarun Badwal $^{2} \cdot$ Neha Badola $^{1}$
}

Received: 19 October 2019 / Accepted: 4 February 2020 / Published online: 11 February 2020

(c) The Author(s) 2020

\begin{abstract}
Water quality assessment of different sources of water in a village was carried out by taking selected significant parameters, namely temperature, $\mathrm{pH}$, conductivity, total dissolved solids (TDS), dissolved oxygen (DO), free carbon dioxide (free $\mathrm{CO}_{2}$ ), alkalinity, hardness, calcium, phosphate, nitrate, chloride and coliform count. All these parameters were analyzed as per the standard protocol of American Public Health Association. Further, seven parameters (pH, TDS, alkalinity, hardness, calcium, nitrates and chloride) were used to calculate water quality index for assessing overall drinking water status of sampling sites. A survey of health status of population of the village was also conducted with the help of questionnaire and interview method to draw the relationship of water quality and health. All selected physicochemical parameters were found under prescribed limits as stated by Indian Standard 10500 and Central Pollution Control Board guidelines. The values for most probable number count were found above the permissible limit of drinking water indicating contamination of coliform at all sites. Further, water quality index for SN1, SN2, SN3, SN4 and SN5 was 17.61, 30.11, 69.73, 25.60 and 47.15, respectively. As per the water quality index, the water samples of natural springs which were away from village were classified under 'excellent' category as compared to supply water samples. The result of survey recorded $38 \%$ population suffered from dysentery, $23 \%$ from diarrhea and 17\% from typhoid. The report of the survey and the presence of coliform suggest that drinking water contamination is leading to waterborne diseases like cholera, dysentery and typhoid. It is also suggested that water quality of all sites except SN3 was suitable for drinking purpose, but disinfection of coliform before use is warranted.
\end{abstract}

Keywords Coliform $\cdot$ Spring $\cdot$ Water quality $\cdot$ Water quality index

\section{Introduction}

The quality of water governs life of an organism on the earth. Hence, researchers around the world are engaged on framing the systematic approach and policy for the longterm conservation of good-quality water. Historical evidences show that change in water quality and quantity due to anthropogenic pressure has lead to vanish many settlements

Jaspal Singh Chauhan

jaspal.env@gmail.com

Tarun Badwal

badwaltarun1@gmail.com

Neha Badola

neha.badola672@gmail.com

1 Department of Himalayan Aquatic Biodiversity, H.N.B Garhwal University, Srinagar, Uttarakhand 246174, India

2 Department of Zoology, H.N.B Garhwal University, Srinagar, Uttarakhand, India of human beings. Quality of water always depends on the source of water, the storage technique and the treatment opted (Lim et al. 2012; Kumpel and Nelson 2013; Wright et al. 2004). Water pollution affects water quality and harms human health, slows economic development and reduces social wealth (Milovanovic 2007). Water quality represents the purity of water and expresses the suitability of water for various uses like drinking, industrial water supply, and irrigation, propagation of aquatic organisms and generation of hydro power. The water quality is assessed in order to determine its potability, safety of human contact and ecosystem health. Poor quality of water is due to high level of organic and inorganic substance that does not fit in the standard limits given by the government. Biological organism like bacteria, viruses and protozoan is also involved in deteriorating the quality of water and further resulting in many diseases (Grabow 1996). The outburst of epidemics in the form of diseases like cholera and diarrhea, which are major waterborne diseases and a global health problem, is the results of 
drinking waters contaminated with waste and sewage (WHO 2000). Bain et al. (2014) estimated that globally, 1.8 billion people use a fecal-contaminated source for drinking water. Out of these, 1.1 billion drink 'moderate'-risk water $(>10 E$. coli/ $100 \mathrm{ml})$. The contamination of the drinking water was found to be dominant in the rural regions (41\%) as compared to the urban areas (12\%). Africa and Southeast Asian countries were recorded using a high percentage of contaminant water, i.e., $53 \%$ and $35 \%$, respectively.

In India, groundwater and river water form the major source of water supply for drinking, domestic and agricultural purposes, but in few hilly states natural streams and springs are serving the purpose smoothly. The Uttarakhand State of India also depends much on its natural water sources for good-quality drinking water for a long time. Deterioration of water quality of natural sources due to the rapid growth of the population, higher demand of agricultural products, unplanned urbanization, overexploitation and other anthropogenic activities had enroute the invasion of many life-threatening diseases in Uttarakhand. High frequencies of natural disasters, increasing human population and unregulated developmental activities have changed the overall status of water quantity and quality in the hills. This has forced the villagers in Uttarakhand to opt for migration to the nearby plain region (Kala and Kala 2006). In Uttarakhand, a large portion of the population (about 77\%) lives in the hilly areas and about $90 \%$ of these populations depend upon the natural spring water for their daily water demand (Jain et al. 2010; Singh et al. 2012). Sumari is a hilly village of Uttarakhand State where people mostly depend on natural water sources to fulfill their water demand for different purposes, especially drinking. The water used is natural and does not have any form of treatment so this research was formulated to know whether such natural sources of water are safe from the perspective of health. The objectives of this research were: to study the health status of Village Sumari, Pauri, Uttarakhand, and to assess the water quality status of natural springs used as a drinking water source by the people of Sumari.

\section{Materials and methods}

\section{Study area}

Sumari is a village of the Pauri District in the Uttarakhand State, India. This village lies at an altitude of 1350-1400 m and at latitudes $30^{\circ}-20^{\prime} \mathrm{N}$ and longitudes $78^{\circ}-81^{\prime} \mathrm{E}$. According to census 2011, the population of the village was 409 , of which 193 are males while 216 are females. The population of this village was initially 500 families as recorded in the 1960s, which has now reduced to more than $60 \%$. The major occupations of the population of this village were agriculture and animal husbandry in the 1960s, but now most families are service class people (Kala and Kala 2006). With the migration of the people of the village, most of the agriculture land is now barren. The village is surrounded by the chirpine and the oak forest.

\section{Sampling sites}

Five water sampling points were spotted in the Village Sumari which were the majorly used by the population of the village. These sampling sources include both natural water and supply water. The detail of the sampling sites is given in Table 1 and Fig. 1.

\section{Survey method}

An initial survey of the health status of the population of the village Sumari was conducted by preparing questionnaires with the consultation of Dr. Prasant Dhanik (MBBS). As per the discussion with the doctor, different symptoms of the waterborne diseases were understood and marked in the questionnaire. All the symptoms were described to the people, and accordingly, the disease was marked in the questionnaire. This method was general interview cum questionnaire approach to understand the health problems of the villagers. A total of 123 people were interviewed of different ages and sexes. A sample of questionnaires used for survey is shown in Fig. 2.

Table 1 Detail of sampling sites

\begin{tabular}{|c|c|c|c|}
\hline S. No. & Sample sites & Site code & Description of site \\
\hline 1 & Gaurikund & SN1 & $\begin{array}{l}\text { Covered underground water source } \\
\text { Used for drinking only, other activities like washing clothes and bathing restricted }\end{array}$ \\
\hline 2 & Tap water & SN2 & $\begin{array}{l}\text { Water supply source } \\
\text { Used for drinking and limited other activities like washing clothes and bathing }\end{array}$ \\
\hline 3 & Stored water & SN3 & $\begin{array}{l}\text { Stored natural water present in the middle of village } \\
\text { Used for various activities like drinking, washing clothes and bathing. }\end{array}$ \\
\hline 4 & Gaumukh & SN4 & $\begin{array}{l}\text { Stored spring natural water } \\
\text { Used for drinking only, other activities like washing clothes and bathing restricted }\end{array}$ \\
\hline 5 & Tank water & SN5 & $\begin{array}{l}\text { Stored tap water } \\
\text { Used for drinking only, other activities like washing clothes and bathing restricted }\end{array}$ \\
\hline
\end{tabular}




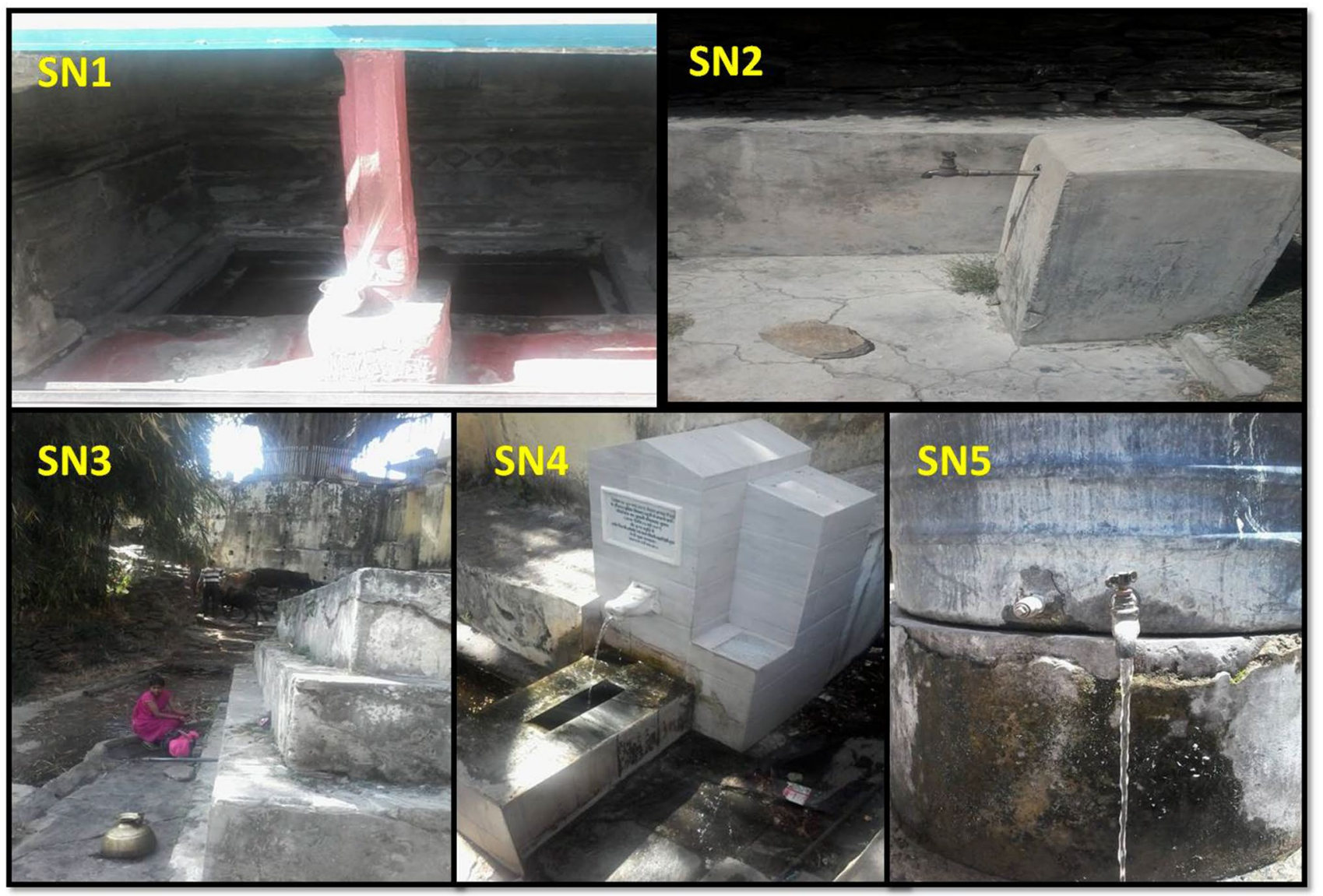

Fig. 1 Sampling site

\section{Physicochemical parameters}

The water samples were collected in polyethylene bottles and were analyzed for the physicochemical characteristics, viz. temperature, $\mathrm{pH}$, conductivity, total dissolved solids (TDS), dissolved oxygen (DO), free $\mathrm{CO}_{2}$, alkalinity, hardness, calcium, phosphate, nitrate, chloride and coliform count, according to standard methods given by American Public Health Association, Washington, DC (APHA 1998). Water temperature, $\mathrm{pH}$ and conductivity, TDS were measured with the help of a thermometer, $\mathrm{pH}$ meter, conductivity meter and TDS meter, respectively. The concentration of DO was measured by the Winkler iodometric titration method. The alkalinity and free $\mathrm{CO}_{2}$ of drinking water were estimated by the titration method; hardness by the ethylene diamine tetra acetic acid (EDTA) titration method; and inorganic phosphorus by the ammonium molybdate method. Calcium is determined by flame photometer, nitrate by spectrophotometer and chloride by Mohr's method.

\section{MPN test}

Water samples from five sites were poured onto the surface of nutrient agar medium after dilutions, and then, incubation was done at $10{ }^{\circ} \mathrm{C}$ until the colonies on a plate stopped increasing in number. The colonies on the agar plates were observed for morphological and growth pattern differences. From this, certain colonies were selected and pure cultures were prepared by streak plate methods. Each culture was stored in test tube slants till further use (Prescott 2002). MPN test is conducted in three steps: 1. presumptive test, 2. confirmed test and 3 . completed test.

\section{Presumptive test}

The MacConkey purple media of single and double strength were prepared in the test tube with Durham's tube and autoclaved. Then, three sets of test tubes containing five tubes in each set are arranged. One set with $10 \mathrm{ml}$ of 
Village-Sumari District-Pauri State-Uttarakhand

NAME :

DATE:

SEX :

AGE:

SOURCE OF DRINKING WATER:

WATER FILTER USED (YES/NO):

DISEASE:

\begin{tabular}{|l|}
\hline DIARRHEA \\
\hline - Abdominal \\
pain \\
- STOOL \\
(hardness) \\
-Urgent need \\
of bowel \\
movement
\end{tabular}

\begin{tabular}{|l|}
\hline DYSENTERY \\
\hline -STOOL ( \\
soft) \\
-blood in stool \\
-Urgent need \\
of bowel \\
movement
\end{tabular}

\begin{tabular}{|l|}
\hline CHOLERA \\
\hline -Watery \\
diarrhea \\
Dehydration \\
- Abdominal \\
Cramps \\
-Fever \\
\end{tabular}

\begin{tabular}{|l|}
\hline TYPHOID \\
\hline -Weakness \\
due to \\
fluid loss. \\
-Fever \\
-Poor \\
appetite \\
- pink \\
rashes of \\
flat \\
\hline
\end{tabular}

\begin{tabular}{|l|}
\hline DENGUE \\
\hline $\begin{array}{l}\text {-Fever } \\
\text { and } \\
\text { headaches } \\
\text {-Pain } \\
\text { behind } \\
\text { eyes } \\
\text {-Muscles } \\
\text { and joint } \\
\text { pain }\end{array}$ \\
\hline
\end{tabular}

\begin{tabular}{|l|}
\hline CALCULUS \\
\hline - Pain on \\
urination \\
-Pain at side \\
and back, \\
below the \\
ribs \\
- fluctuation \\
in pain \\
\end{tabular}

Medical history :

REMARK :

\section{SIGNATURE:}

Fig. 2 Questionnaire used in survey

double strength (DS) and other two containing $10 \mathrm{ml}$ of single strength (SS) media were placed. Then, $10 \mathrm{ml}$ of water sample was transferred to each of the DS broth tubes using sterile pipette. Further, $1 \mathrm{ml}$ of water sample to each of the five tubes of one set of SS broth and $0.1 \mathrm{ml}$ water to five tubes of the remaining last set of SS broth tubes were transferred. The tubes were incubated at $37{ }^{\circ} \mathrm{C}$ for $24 \mathrm{~h}$ and then observed for the gas production in the Durham's tube and color change of the media. The number of positive results from each set was recorded and compared with the standard chart to give presumptive coliform count per $100 \mathrm{ml}$ water sample. 


\section{Confirmed test}

The samples from the positive tube of the presumptive test were streaked on the EMB lactose plates and are incubated at $37{ }^{\circ} \mathrm{C}$ for $24 \mathrm{~h}$. The bacterial colonies with black centers or metallic sheen were observed marking positive confirmed test.

\section{Completed test}

The typical colonies of coliform (with metallic sheen) were selected, then inoculated on lactose broth and agar slant and incubated at $37{ }^{\circ} \mathrm{C}$ for $24 \mathrm{~h}$. The production of gas shows the presence of coliform group, and the completed test was positive.

\section{Water quality index}

Water quality index (WQI) is a technique of rating that provides the composite influence of each of the selected water quality parameters on the overall quality of water. Assessment of the water quality for various proposes like drinking, bathing and irrigation is carried out by the water quality indexes (Zahedi 2017). In this study, we considered the standards recommended by IS-10500 (2012) for the calculation of WQI. The weights for various water quality parameters are considered to be inversely proportional to the standard values (Naik and Purohit 2001). WQI was calculated by weighted index method to understand the suitability of spring water for drinking purposes (Chauhan and Rai 2014; Padmanabha and Belagali 2005; Tiwari and Mishra 1985; Banerjee and Srivastava 2009). Out of total studied parameters, pH, TDS, alkalinity, hardness, calcium, nitrate and chloride parameters were selected for the computation of water quality index (Table 2).

Water quality index was calculated by the formula:

$\mathrm{WQI}=\sum_{i=1}^{n} W_{i} q_{i}$

Table 2 Selected values for water quality index calculation

\begin{tabular}{lllll}
\hline Parameter & $\begin{array}{l}\text { Water } \\
\text { quality } \\
\text { standard }\end{array}$ & Recommended agency & $V_{i}$ & $W_{i}$ \\
\hline pH & $6.5-8.5$ & IS 10500, CPCB & 7 & 0.721153 \\
TDS (mg/l) & 500 & IS 10500 & 0 & 0.010817 \\
Alkalinity (mg/l) & 200 & IS 10500 & 0 & 0.027043 \\
Hardness (mg/l) & 200 & IS 10500 & 0 & 0.027043 \\
Calcium (mg/l) & 75 & IS 10500 & 0 & 0.072115 \\
Nitrate (mg/l) & 45 & IS 10500 & 0 & 0.120192 \\
Chloride (mg/l) & 250 & IS 10500 & 0 & 0.021635 \\
\hline
\end{tabular}

where $w_{i}$ is the weightage factor of the $i$ th parameter and $q_{i}$ is the quality rating of the $i$ th parameter. The $w_{i}$ can be calculated from the following equation:

$w_{i}=\frac{K}{\mathrm{Sn}}$

$K=\frac{1}{\frac{1}{V_{\mathrm{s} 1}}+\frac{1}{V_{\mathrm{s} 2}}+\frac{1}{V_{\mathrm{s} 3}}+\cdots+1 / V_{\mathrm{sn}}}$

$q_{i}=\left[\frac{V_{\mathrm{a}}-V_{i}}{V_{\mathrm{s}}-V_{i}}\right] \times 100$

where $V_{\mathrm{a}}$ is the actual value obtained from laboratory analysis of $i$ th parameter; $V_{\mathrm{s}}$ is the standard value of $i$ th parameter from standard table; $V_{i}$ is the ideal value (for $\mathrm{pH}=7$, and for other parameters, it is equivalent to zero).

Using the water quality index, all samples were categorized into five classes as excellent (0-25), good (26-50), moderately polluted (51-75), severely polluted (76-100) and unfit (above 100) based on their suitability for human consumption.

\section{Result and discussion}

\section{Survey report}

Based on the survey report, $38 \%$ of the population suffers from dysentery, $23 \%$ from diarrhea, $17 \%$ from typhoid, $13 \%$ from calculus, $4 \%$ from cholera and $2 \%$ from dengue of the total studied population of 123 (Fig. 3). During the study period, $75 \%$ of the total population was found to be infected from waterborne diseases and this was further clarified while studying water quality parameters individually. Contamination of water with coliform at all sites justifies high percentage of diseases like diarrhea, dysentery and typhoid. Further, it was observed that high percentage of calculus disease may also be correlated with the high value of hardness recorded in this study. Twenty-five percent of the population was found healthy without any waterborne diseases at the time of survey.

\section{Coliform test}

All the five sites were found to have the coliform contamination ranged between 1 and 12, maximum at site SN4 and minimum at $\mathrm{SN} 1$, which is more than prescribed limit of zero as per BIS 10500 (2012). The site SN4 was found to have the highest coliform count $12 / 100 \mathrm{ml}$ during the study period (Table 3). These data clearly show that there is some 
Fig. 3 Graph showing infected individuals from various water borne diseases
Table 3 Water quality parameters of water samples collected from study sites

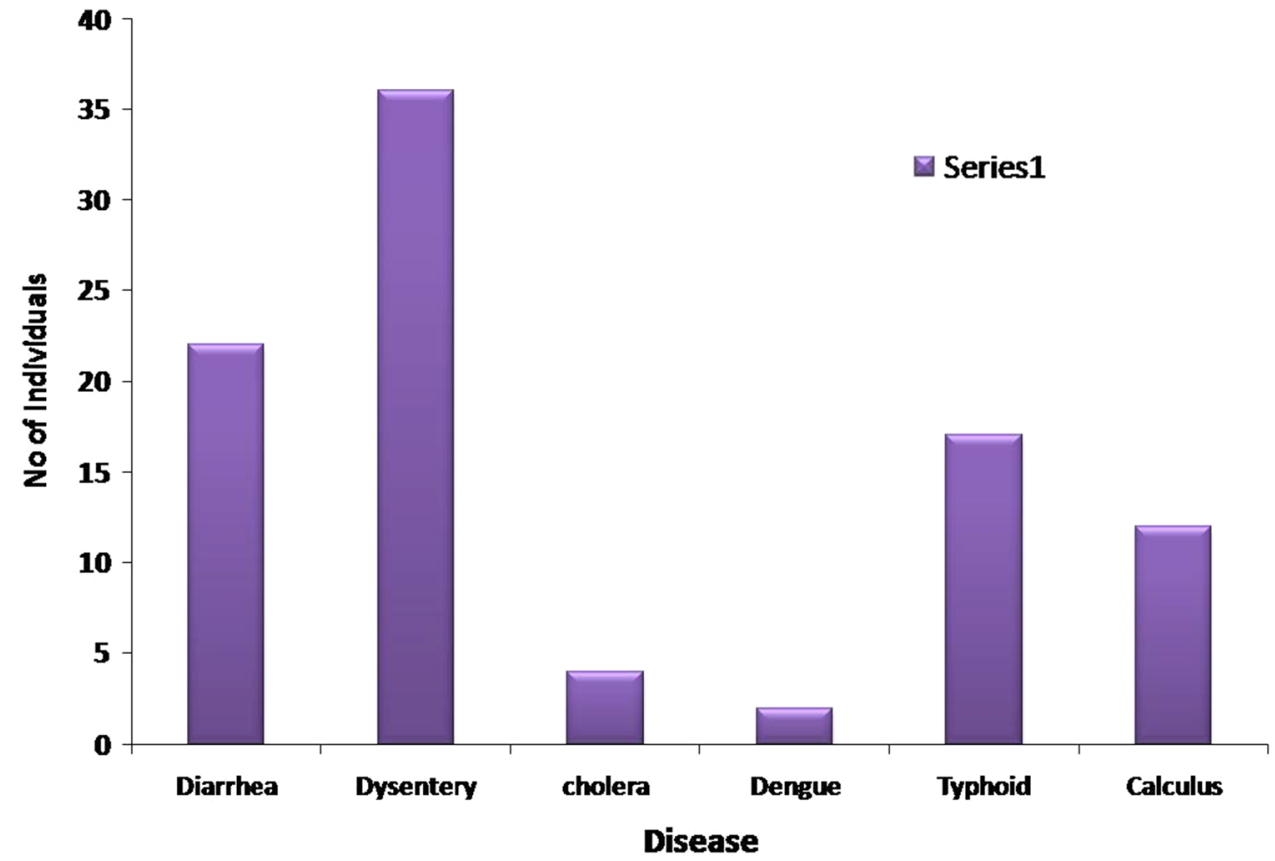

\begin{tabular}{|c|c|c|c|c|c|}
\hline \multirow[t]{2}{*}{ Parameters } & \multicolumn{5}{|l|}{ Sampling sites } \\
\hline & $\mathrm{SN} 1(X \pm \mathrm{SD})$ & $\mathrm{SN} 2(X \pm \mathrm{SD})$ & $\mathrm{SN} 3(X \pm \mathrm{SD})$ & SN4 $(X \pm \mathrm{SD})$ & SN5 $(X \pm \mathrm{SD})$ \\
\hline $\mathrm{pH}$ & $7.1 \pm 0.2$ & $7.19 \pm 0.2$ & $6.54 \pm 0.1$ & $6.84 \pm 0.11$ & $6.69 \pm 0.2$ \\
\hline Water temperature $\left({ }^{\circ} \mathrm{C}\right)$ & $13.2 \pm 0.1$ & $13.6 \pm 0.12$ & $13.2 \pm 0.00$ & $14.1 \pm 0.1$ & $13.5 \pm 0.3$ \\
\hline Conductivity $(\mu \mathrm{S} / \mathrm{cm})$ & $132 \pm 4$ & $139 \pm 2.5$ & $137 \pm 3.6$ & $145 \pm 3.3$ & $140 \pm 5.8$ \\
\hline TDS (mg/l) & $35.5 \pm 2.6$ & $26.5 \pm 1.9$ & $72.5 \pm 3.3$ & $48.5 \pm 1.8$ & $42.5 \pm 0.5$ \\
\hline DO (mg/l) & $2.8 \pm 0.012$ & $2.5 \pm 0.10$ & $4.4 \pm 0.00$ & $3.4 \pm 0.012$ & $2.9 \pm 0.002$ \\
\hline Free $\mathrm{CO}_{2}(\mathrm{mg} / \mathrm{l})$ & $4.1 \pm 0.013$ & $4.4 \pm 0.12$ & $6.2 \pm 0.16$ & $2.6 \pm 0.10$ & $3.4 \pm 0.1$ \\
\hline Alkalinity $(\mathrm{mg} / \mathrm{l})$ & $120 \pm 4.0$ & $95 \pm 1.9$ & $105 \pm 7.2$ & $75 \pm 5.4$ & $71 \pm 3.2$ \\
\hline Hardness (mg/l) & $32.8 \pm 0.1$ & $29.6 \pm 1.1$ & $36.8 \pm 1.6$ & $22.4 \pm 1.1$ & $20.0 \pm 0.8$ \\
\hline Calcium (mg/l) & $10.2 \pm 0.2$ & $9.6 \pm 0.4$ & $12.8 \pm 0.01$ & $10.8 \pm 0.1$ & $11.1 \pm 0.01$ \\
\hline Phosphate (mg/l) & $0.062 \pm 0.001$ & $0.054 \pm 0.0012$ & $0.068 \pm 0.001$ & $0.038 \pm 0.01$ & $0.042 \pm 0.001$ \\
\hline Nitrate $(\mathrm{mg} / \mathrm{l})$ & $0.16 \pm 0.00$ & $0.10 \pm 0.001$ & $0.19 \pm 0.00$ & $0.12 \pm 0.00$ & $0.14 \pm 0.003$ \\
\hline Chloride (mg/l) & $2.6 \pm 0.021$ & $1.9 \pm 0.011$ & $2.8 \pm 0.02$ & $2.7 \pm 0.01$ & $1.5 \pm 0.004$ \\
\hline Coliform count $/ 100 \mathrm{ml}$ & $01 \pm 0$ & $04 \pm 0$ & $06 \pm 0.1$ & $12 \pm 0.2$ & $08 \pm 0.4$ \\
\hline
\end{tabular}

source of fecal matter that is contaminating the drinking water of different sites. The fecal matter may result due to open defecation or diffusion of sewage water in the drinking water source. Though these fecal bacteria are not pathogenic themselves, they are useful in providing information about other pathogenic organisms that result due to fecal contamination like protozoa, multi-cellular parasites, bacteria and viruses. Thus, during this research, the presence of coliform bacteria indicates the assurance of fecal contamination in the water body, which indicates increased risk of health and unsuitability of water for drinking. It can greatly affect the health of the people drinking that water by causing disease like cholera, typhoid, dysentery, etc. In a similar study by Amanatidou et al. (2007), the presence of total coliform was recorded in the spring water sources of Kozani, Western Macedonia. In rural areas, lack of proper sanitation is increasing health risk and continuously consuming contaminated water can lead to serious diseases, and in particular, it will affect infants (Suthar et al. 2009). The site SN4 is surrounded by many houses so many nonpoint sources like bathing, washing and animal husbandry may be the probable reason for high values of coliform there. 


\section{Physicochemical analysis}

The physicochemical parameters recorded from analysis of water samples are presented in Table 3.

The temperature of the water samples ranged between 13.2 and $14.1^{\circ} \mathrm{C}$ with an average of $13.5^{\circ} \mathrm{C}$, maximum at site SN4 and minimum at site SN1 and SN3. Temperature can be considered as an important factor in natural drinking water sources as temperature can affect mostly all physicochemical processes (Delpla et al. 2009). Moreover, temperature controls rate of reactions, metabolic activities and growth of living organisms in water. The $\mathrm{pH}$ of the samples ranged between 6.54 and 7.19 , with an average of 6.87 . The maximum value noted at SN2 which was municipal water source and the minimum at $\mathrm{SN} 3$ which was natural source lie between the recommended values (6.5-8.5) by IS 10500 . However, among all sites, SN1, which is natural water kund, had the ideal $\mathrm{pH}$ value 7.1 while other sampling sites were found to be slightly acidic in nature. Acidic nature of water samples was also observed by Bhat et al. (2010) and Kumar et al. (1997) while studying natural springs of Kashmir and Almora (Uttarakhand) in India, respectively. Acidic nature of water is a characteristic of oligotrophic water bodies indicating its good quality (Soni et al. 2013). The conductivity of the water samples ranged between 132 and $145 \mu \mathrm{S} /$ $\mathrm{cm}$ with an average of $138.6 \mu \mathrm{S} / \mathrm{cm}$; maximum at SN4 and minimum at SN1. The low value of conductivity indicates the less number of ions present in the water sample, making it suitable to drink. The value of TDS for the samples ranged between 26.5 and $72.5 \mathrm{mg} / \mathrm{l}$ with an average of $45.1 \mathrm{mg} / \mathrm{l}$ maximum at site SN3 and minimum at SN2; these values are quite less than the recommended values by IS 10500, which is $500 \mathrm{mg} / \mathrm{l}$. Usually, the conductivity and TDS are directly related to each other, i.e., the more the number of ions, the more will be the value of TDS and, furthermore, will be the conductivity (Yilmaz and Koç 2014).

DO of the samples ranged between 2.5 and $4.4 \mathrm{mg} / \mathrm{l}$ with an average of $3.2 \mathrm{mg} / \mathrm{l}$ maximum at site $\mathrm{SN} 3$ and minimum at site SN2. These values were below the minimum recommended values by CPCB $(6.0 \mathrm{mg} / \mathrm{l}$ or more $)$ for class ' $\mathrm{A}$ ' category water that is drinking water after conventional treatment. This does not influence the health of the person consuming the water but is responsible for various biological activities in the water. Free $\mathrm{CO}_{2}$ of the samples ranged between 2.6 and $6.2 \mathrm{mg} / \mathrm{l}$ with an average of $4.14 \mathrm{mg} / \mathrm{l}$ maximum at site SN3 and minimum at SN4. The common source of free $\mathrm{CO}_{2}$ is the respiratory activity of living organisms in the water and decomposition of dead decay matter in water. The change in the value of free $\mathrm{CO}_{2}$ in water influences the alkalinity, acidity, hardness by forming carbonates and bicarbonates (Allan and Castillo 2007).

Alkalinity of the samples ranges between 71 and $120 \mathrm{mg} / \mathrm{l}$ with an average of $93.2 \mathrm{mg} / \mathrm{l}$ maximum at site SN1 and minimum at SN5; these values were under the recommended values by IS 10500 , which is $200 \mathrm{mg} / \mathrm{l}$. Hardness of the samples ranged between 20 and $36.8 \mathrm{mg} / \mathrm{l}$ with an average of $28.32 \mathrm{mg} / \mathrm{l}$ maximum at site SN3 and minimum at SN5; these values were under the recommended values by IS 10500 which is $200 \mathrm{mg} / \mathrm{l}$. The hardness of the water is due to the minerals like calcium and magnesium that pour in the water during its journey through rocks and soil. Calcium in the samples ranged between 9.6 and $12.8 \mathrm{mg} / \mathrm{l}$ with an average of $10.9 \mathrm{mg} / \mathrm{l}$, maximum at site $\mathrm{SN} 3$ and minimum at $\mathrm{SN} 2$; these values were under the recommended values by IS 10500 which is $75 \mathrm{mg} / \mathrm{l}$. Phosphate in the samples ranged between 0.038 and $0.068 \mathrm{mg} / \mathrm{l}$ with an average of $0.053 \mathrm{mg} / \mathrm{l}$, maximum at site SN3 and minimum at SN4; these values were under the recommended values by WHO, which is $1.5 \mathrm{mg} / \mathrm{l}$. At low concentration, phosphate is nontoxic, but extremely high level of phosphate can cause health effects. Nitrate in the samples ranged between 0.1 and $0.19 \mathrm{mg} / \mathrm{l}$ with an average of $0.14 \mathrm{mg} / \mathrm{l}$, maximum at site SN3 and minimum at SN2; these values were under the recommended values by IS 10500 , which is $45 \mathrm{mg} / \mathrm{l}$. The less value of nitrate indicates only natural addition of nitrate in the spring water. Similar trends of result were observed by Tripathi et al. (2015) while studying spring water of Dehradun, but another study of Kumar et al. (1997) and Amanatidou et al. (2007) recorded high concentration of nitrates in water samples of springs at Almora, Uttarakhand, and potable water supply sources in the area of Kozani, Western Macedonia, respectively. The possible sources of nitrate ions in drinking water are excessive use of agricultural fertilizers, decayed organic matter, domestic effluent, industrial discharges, leaching and atmospheric precipitation (Makhijani and Manoharan 1999). The high concentration of nitrate is responsible for disease methemoglobinemia or blue baby syndrome in babies. So, it is suggested that water with nitrite levels exceeding $1.0 \mathrm{mg} / \mathrm{l}$ should not be used for baby feeding (Puri and Kumar 2012). In the present study, the water from all sources was safe for baby feeding as all the values were well below $1.0 \mathrm{mg} / \mathrm{l}$. Chloride in the samples ranged between 1.5 and $2.8 \mathrm{mg} / \mathrm{l}$ with an average of $2.3 \mathrm{mg} / \mathrm{l}$, maximum at site SN3 and minimum at SN5; these values were under the recommended values by IS 10500 , which is $250 \mathrm{mg} / \mathrm{l}$. The most common sources of chlorides into surface water are: rocks containing chlorides, agricultural runoff, industrial water, effluent from waste water treatment plants. Our study area was deprived of all such sources, except geological contribution; hence, the values were recorded quite low. Chlorides have the potential to corrode metals and affect food products in taste. As an essential element, chloride is important for the living organisms in small quantity for proper growth and development. Usually, chlorides do not harm human body, but as a salt of sodium, 
Fig. 4 Graph showing water quality index of different sites

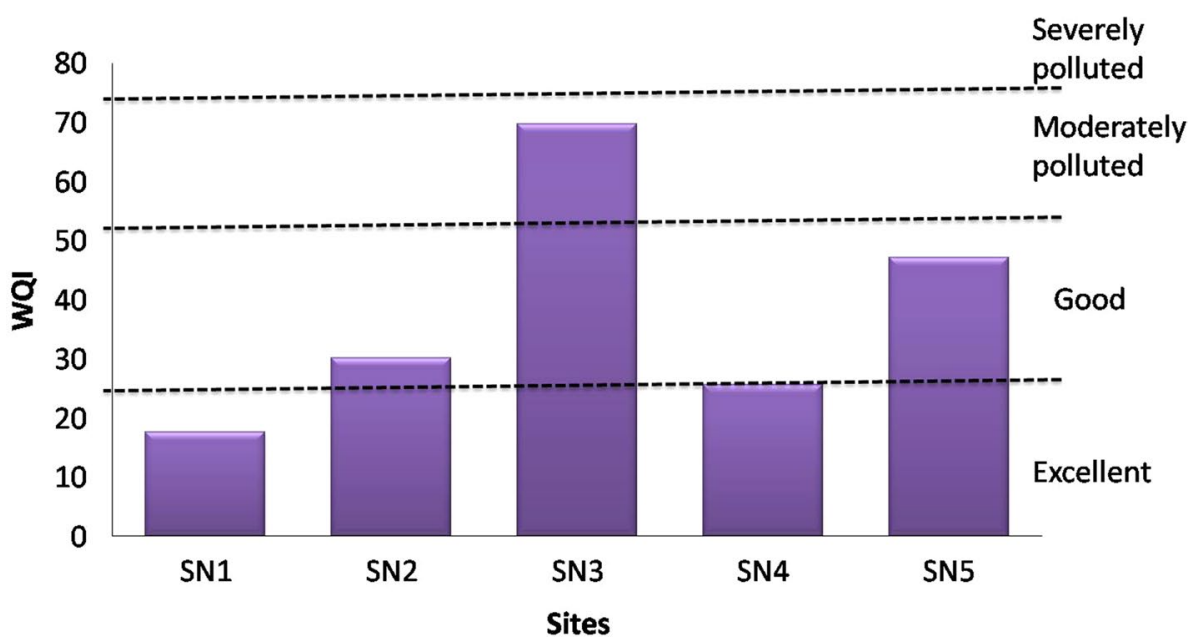

it has been potential to impair the functions of heart and kidney (Puri and Kumar 2012).

The water quality index of the samples ranged between 17.61 and 69.73, with an average of 38.04. Water samples were collected from different water sources of village which includes natural water and supply water. Water quality index of site SN1, site SN2, site SN3, site SN4 and site SN5 is 17.61, 30.11, 69.73, 25.59 and 47.15, respectively (Fig. 4).

According to the water quality categorization, site SN1 and site SN4 fall under the excellent category, while site SN2 and site SN5 fall in good category and site SN3 falls in moderately polluted category. This explains that water from the natural sources (SN1 and SN4) and municipal supply source (SN2 and SN5) is fit for drinking after general disinfection process, while one of the natural source waters (SN3) is found polluted and hence is completely unfit for drinking purpose without treatment. Excellent status of site SN1 is because of its location and formation. It is a closed kund protected from every side, and its water is fed by groundwater spring which protects it from contaminating from different nonpoint sources of pollution. The other sites are prone to anthropocentric activities, creating the possibility of contamination of drinking water sources. Many other researchers also applied water quality index for different water resources like lake water (Sidi et al. 2019), groundwater (Abbasnia et al. 2018; Fayyadh et al. 2019; Adimalla 2019; Suvarna et al. 2020), dam water (Arab et al. 2019) to categorize the suitability of water for different purposes.

\section{Conclusion}

The present study applied the physicochemical, bacteriological and survey approach to understand the significance of the natural water resources and their management in hilly areas. The result revealed that all the studied physicochemical parameters were well within permissible limits and do not require any form of treatment. But the presence of the colonies of coliform in all the samples indicated a high bacteriological contamination due to which a major fraction of the village population suffered from dysentery, diarrhea and typhoid. This may be attributed to the polluted water diffused from the local drains and runoff from nearby areas and unsanitary practices of open defecation. Further, the water quality index of the water sample from the study area falls under excellent, good and moderately polluted category, explaining the need of management practices to maintain and improve the quality. Finally, this study concludes that if the proper disinfection of the bacteria is carried out, the water of the natural sources is best for the drinking purpose. But if the treatment of the bacteria is not conducted, it will cause several waterborne diseases like diarrhea, typhoid and dysentery as observed in the survey. Here are a few suggestions to protect the natural water resources from the contamination to keep life safe and healthy.

- Proper sanitation practices should be opted near the water resources.

- Village bodies to initiate regular cleaning of the water resources.

- Regularly quality tests should be conducted to protect the people from waterborne diseases.

- Proper urban drainage systems in the area to minimize the diffusion of contaminants.

- Formulations of the policies for the protection and conservation of the natural springs in Uttarakhand. 


\section{Compliance with ethical standards}

Conflict of interest The authors declare no conflict of interest.

Open Access This article is licensed under a Creative Commons Attribution 4.0 International License, which permits use, sharing, adaptation, distribution and reproduction in any medium or format, as long as you give appropriate credit to the original author(s) and the source, provide a link to the Creative Commons licence, and indicate if changes were made. The images or other third party material in this article are included in the article's Creative Commons licence, unless indicated otherwise in a credit line to the material. If material is not included in the article's Creative Commons licence and your intended use is not permitted by statutory regulation or exceeds the permitted use, you will need to obtain permission directly from the copyright holder. To view a copy of this licence, visit http://creativecommons.org/licenses/by/4.0/.

\section{References}

Abbasnia A, Yousefi N, Mahvi AH, Nabizadeh R, Radfard M, Yousefi M, Alimohammadi M (2018) Evaluation of groundwater quality using water quality index and its suitability for assessing water for drinking and irrigation purposes: case study of Sistan and Baluchistan province (Iran). J Hum Ecol Risk Assess Int J 4:988-1005

Adimalla N (2019) Controlling factors and mechanism of groundwater quality variation in semiarid region of South India: an approach of water quality index (WQI) and health risk assessment (HRA). Environ Geochem Health 4-8:1-28

Allan JD, Castillo MM (2007) Stream ecology: structure and function of running waters, 2nd edn. Chapman and Hall, New York

Amanatidou E, Adamidou K, Trikoilidou E, Katsiouli F, Patrikaki O, Tsikritzisa L (2007) Physicochemical and microbiological characteristics of the potable water supply sources in the area of Kozani, Western Macedonia. Desalination 213:1-8

APHA (1998) Standard methods for the examination of water and wastewater. American Public Health Association Inc, New York

Arab S, Bouchelouche D, Hamil S, Arab A (2019) Application of water quality index for surface water quality assessment Boukourdane Dam, Algeria. In: Chaminé HI, Barbieri M, Kisi O, Chen M, Merkel BJ (eds) Advances in sustainable and environmental hydrology, hydrogeology, hydrochemistry and water resources. Proceedings of the 1st Springer conference of the Arabian journal of geosciences (CAJG-1), Tunisia 2018. Springer International Publishing, pp 85-88

Bain R, Cronk R, Wright J, Yang H, Bartram J (2014) Fecal contamination of drinking water in developing countries: a systematic review and meta-analysis. PLoS Med 11:e1001644

Banerjee T, Srivastava RK (2009) Application of water quality index for assessment of surface water quality surrounding integrated industrial estate-Pantnagar. Water Sci Technol 60(8):2041-2053

Bhat SU, Pandit AK, Mudathir R (2010) Limnological investigation of three freshwater springs of Pulwama district-Kashmir valley. Recent Res Sci Technol 2(2):88-94

BIS (2012) Indian standards specifications for drinking water (second revision). Bureau of Indian standards, IS:10500, New Delhi

Chauhan JS, Rai JPN (2014) Assessment of potability of groundwater around ferti-irrigated area of industrial region. Octa J Environ Res 2(4):321-328

Delpla I, Jung AV, Baures E, Clement M, Thomas O (2009) Impacts of climate change on surface water quality in relation to drinking water production. Environ Int 35:1225-1233

Fayyadh R, Ismail Z, Hussain HM, Aleya L (2019) Physicochemical properties and water quality index of groundwater of selected wells in Najaf City Southern Iraq. J Eng Appl Sci 14(7):9995-10009

Grabow W (1996) Waterborne diseases: update on water quality assessment and control. Water Sa 22(2):193-202

Jain CK, Bandyopadhyay A, Bhadra A (2010) Assessment of ground water quality for drinking purpose, District Nainital, Uttarakhand, India. Environ Monit Assess 166:663-676

Kala R, Kala CP (2006) Indigenous water conservation technology of Sumari village, Uttaranchal

Kumar K, Rawat DS, Joshi R (1997) Chemistry of springwater in Almora, Central Himalaya, India. Environ Geol 31(3/4):150-156

Kumpel E, Nelson KL (2013) Comparing microbial water quality in an intermittent and continuous piped water supply. Water Res 47:5176-5188

Lim SS, Vos T, Flaxman AD et al (2012) A comparative risk assessment of burden of disease and injury attributable to 67 risk factors and risk factor clusters in 21 regions, 1990-2010: a systematic analysis for the Global Burden of Disease Study 2010. Lancet 380:2224-2260

Makhijani SD, Manoharan A (1999) Nitrate pollution problem in drinking watersources: monitoring and surveillance. Paper presented in the workshop water quality field test kits for Arsenic, Fluoride and Nitrate held from 8-9 Sept 1999 at ITRC, Lucknow

Milovanovic M (2007) Water quality assessment and determination of pollution sources along the Axios/Vardar River, Southeastern Europe. Desalination 213(1-3):159-173

Naik S, Purohit KM (2001) Studies on water quality of River Brahmani in Sundargarh district, Orissa. Indian J Environ Ecoplan 5(2):397-402

Padmanabha B, Belagali SL (2005) Comparative study on water quality index of the four lakes in the Mysore city. Indian J Environ Prot 25(10):873-876

Prescott H (2002) Laboratory exercises in microbiology, 5th edn. McGraw Hill Companies, New York

Puri A, Kumar M (2012) A review of permissible limits of drinking water. Indian J Occup Environ Med 16(1):40

Sidi YMO, Fakhaoui M, Bellaouchou A, Kankou MS, Dick BA (2019) Application of water quality index (WQI) for the assessment of natural sources of water in rural areas of lake aleg in Mauritania. Int J Civ Eng Technol 10(02):940-950

Singh P, Tyagi S, Dobhal R, Singh R, Seth R, Mohan M (2012) Evaluation of water quantity and quality status of drinking water sector of Uttarakhand, India. Anal Chem Lett 2:198-205

Soni VK, Visavadia M, Gosai C, Hussain MD, Mewada MS, Gor S, Salahuddin K (2013) Evaluation of physico-chemical and microbial parameters on water quality of Narmada River, India. Afr J Environ Sci Technol 7:496-503

Suthar S, Chhimpa V, Singh S (2009) Bacterial contamination in drinking water: a case study in rural areas of northern Rajasthan, India. Environ Monit Assess 159:43

Suvarna B, Reddy YS, Sunitha V, Reddy BM, Prasad M, Reddy (2020) Data on application of water quality index method for appraisal of water quality in around cement industrial corridor, Yerraguntla Mandal, Y.S.R District, A.P South India. Data Brief 28:104872

Tiwari TN, Mishra M (1985) A preliminary assignment of water quality index of major Indian rivers. Indian J Environ Prot 5(4):276-279

Tripathi DK, Pandey G, Jain CK (2015). Physicochemical analysis of selected springs water samples of Dehradun City, Uttarakhand, India. Int J for Innov Res Sci Tech 2(5):99-103

WHO (2000) The world health report: Health systems: improving performance, World Health Organization, Geneva, Switzerland

Wright J, Gundry S, Conroy R (2004) Household drinking water in developing countries: a systematic review of microbiological contamination between source and point-of-use. Trop Med Int Health 9:106-117 
Yilmaz E, Koç C (2014) Physically and chemically evaluation for the water quality criteria in a farm on Akcay. J Water Resour Prot 6:63-67

Zahedi S (2017) Modification of expected conflicts between drinking water quality index and irrigation water quality index in water quality ranking of shared extraction wells using multi criteria decision making techniques. Ecol Indic 83:368-379
Publisher's Note Springer Nature remains neutral with regard to jurisdictional claims in published maps and institutional affiliations. 